RELACult - Revista Latino-Americana de Estudos em Cultura e Sociedade

Revista Latinoamericana de Estudios en Cultura y Sociedad | Latin American Journal of Studies in Culture and Society

V. 03, ed. especial, ago., 2017, p. 121-128 | relacult.claec.org e-ISSN 2016/Atual: 2525-7870 | e-ISSN 2015/2016: 2447-018X

\title{
O Turbante como Representatividade da Identificação Negra
}

\author{
El turbante como Representatividad de la identificación Negro
}

The Turban as Representation of the Black Identification

\author{
Damaris de Lima Santos ${ }^{1}$ \\ Raicilane Barbosa de Jesus Santana ${ }^{2}$ \\ Renan Lima da Silva ${ }^{3}$
}

\begin{abstract}
Resumo
Esse trabalho traz discussões em torno da representatividade e identificação negra do turbante. Apresenta dados considerando desde as origens do acessório no Brasil, até representação do mesmo difundida pela moda atual em mídias sociais. Características de patrimônio imaterial também são apontadas enquanto relevantes na difusão de saberes culturais. Assim como questões a respeito da memória, paisagem cultural e as tramas geradas pelo uso do adorno. Conclui com reflexão da relevância em propagar o significado do turbante enquanto identidade negra e a necessidade de uma sensibilização em torno de seu uso.
\end{abstract}

Palavras-chave: Identificação Negra; Patrimônio; Representatividade; Turbante.

\section{Resumen}

Este trabajo trae discusiones acerca de la representatividad y la identificación del turbante negro. Presenta los datos de los orígenes del accesorio en Brasil, para la representación de la misma se extendió por la moda actual en los medios sociales. Elementos del patrimonio inmaterial también se identifican como relevantes para la difusión de los conocimientos culturales. Así como preguntas sobre la memoria, el paisaje cultural y los marcos generadas por el uso de adorno. Concluye con la reflexión de la relevancia para propagar la importancia del turbante mientras que la identidad negro y la necesidad de conciencia en torno a su uso.

Palabras claves: Identificación Negro; Patrimonio; Representatividad; Turbante.

\section{Abstract}

This work brings discussions about the representativeness and black identification of the turban. It presents data considering from the origins of the accessory in Brazil, Until its representation diffused by the current fashion in social media. Characteristics of intangible heritage are also pointed out while relevant in the diffusion of cultural knowledge. As well as questions about memory, cultural landscape and the patterns generated by the use of the adornment. It concludes with reflection of relevance in propagating the meaning of the turban as black identity and the need for an awareness around its use.

Keywords: Black Identification; Heritaje; Representativeness; Turban.

\footnotetext{
1 (Bacharelanda em Produção e Política Cultural; Universidade Federal do Pampa - UNIPAMPA; Jaguarão, Rio Grande do Sul, Brasil; damaris.limas@gmail.com)

2 (Bacharelanda em Produção e Política Cultural; Universidade Federal do Pampa - UNIPAMPA; Jaguarão, Rio Grande do Sul, Brasil; raici.miss@gmail.com)

3 (Mestre em Turismo; Docente na Universidade Federal do Pampa - UNIPAMPA; Jaguarão, Rio Grande do Sul, Brasil; renan.turismo@gmail.com)
} 


\section{Introdução}

O presente trabalho visa contextualizar sobre o simbolismo característico do uso do turbante. Sua origem, até hoje não se tem conhecimento ao certo. Foi utilizado por povos do Oriente, como os árabes e indianos que usam até hoje como adereço religioso. Na África o turbante faz parte da indumentária de sua população. Conhecido também como OJÁ, seu uso é feito por médiuns em rituais na Umbanda e no Candomblé para cobrir a cabeça no intuito de proteção e também em respeito ao sagrado. Para além de acessório, o turbante chegou ao Brasil por influência de escravos sendo utilizado inicialmente por baianas e religiosos/as de terreiros de candomblé. Seu uso expressa também uma forma de resistência contra preconceitos, discriminação e estereótipos existentes. O turbante pode ser usado por mulheres, homens, crianças e idosos. Diferentemente de outros acessórios, carrega em si um marco de identificação da cultura negra.

A escritora Borges (2015), afirma que o turbante enquanto parte integrante nas religiões africanas possui elo espiritual e traz consigo significados diferenciados conforme suas cores e amarrações. Como adereço de proteção da cabeça, carrega em si simbolismo de fé. As mulheres vindas da África faziam uso do turbante e de roupas usadas no país de origem reproduzindo e legitimando seus costumes no Brasil. Conforme Brito (2011), em 1930 o estilista francês Paul Poiret, adentrou o uso do acessório na chamada alta costura e o mesmo foi visto em mulheres sofisticadas da época. Em 1960, houve o surgimento do movimento do orgulho negro nos Estados Unidos. Esse contribuiu de certa maneira para que o uso do turbante voltasse ao cenário de afirmação de cultura negra.

Recentemente, o turbante passou a atingir maior proporção a partir do momento em que ganhou repercussão na moda por meio da mídia. Contudo, essa projeção não levou em consideração suas características identitárias, considerando somente sua função estética. Isso contribui para construção equivocada do imaginário social em torno desse acessório. Entendendo esse cenário conturbado, faz-se necessário uma reflexão em torno do tema. Buscando afirmar sua importância enquanto identidade negra e legitimar seu uso protagonizado por essa população, convém patrimonializar esse bem. Tem-se com isso o objetivo de refletir sobre o uso do turbante enquanto patrimônio cultural e de representatividade negra. Pensou-se em suas características patrimoniais materiais e imateriais. Por não se tratar de um simples objeto, sua materialidade está estritamente vinculada ao simbolismo imaterial de seu uso.

Além de permitir o empoderamento de mulheres negras, o uso do turbante possibilita atingir respeito e resgate da ancestralidade afro. Por não se tratar de um simples "pedaço de 
tecido", sua memória precisa ser reconhecida e difundida. Identificar seu uso como símbolo de patrimônio cultural, integrante de uma trama de subjetividades é fundamental para alcance de legítima consciência de sua representatividade negra na sociedade.

\section{Referencial Teórico}

Mediante discussões de Monteiro e Ferreira (2005), pode-se afirmar que através da cultura negra-africana introduzida no território brasileiro desde o período colonial do século XVI, eis que foi possível herdar aspectos importantes para identificar a chamada cultura afrobrasileira. Em meio a várias situações de migrações que ocorreram, ainda assim se manteve alguns elementos culturais. Em especial, as escravas da época utilizavam adereços com características peculiares a matriz africana, como por exemplo, saia de bico de renda, batas e turbante.

Tratando-se do aspecto específico do traje de mulheres negras, esse é um tanto característico das escravas no Brasil, sobretudo descendentes de memória africana. No século XIX pode-se destacar que o traje enquanto objeto cultural, para Nogueira (2002, p.142, apud MONTEIRO; FERREIRA, 2005, p. 388), “[...] não é apenas cor, textura, matéria-prima, forma e função. O objeto, é tudo isto, e mais história, contexto cultural, emoção, experiência sensorial e comunicação corporal". Para além de uma valorização material de tais bens, é de grande relevância também o reconhecimento do conjunto de significados atribuídos aos mesmos.

Através do vestuário é possível transmitir significados e valores de uma cultura. As roupas destinadas ao uso por parte das escravas era composto por saia rodada, camisu com renda renascença, turbante branco ou colorido e pano-da-costa. Essas vestimentas eram utilizadas no dia-a-dia de trabalho das mulheres negras, tanto nas plantações, como também nos trabalhos domésticos. Em diferentes ocasiões as vestimentas eram acrescentadas de jóias, correntões e bata encomendadas pelos senhores de escravos de maneira a expor poder e as riquezas conquistadas. Os elementos utilizados por elas eram carregados de significados. $\mathrm{O}$ turbante reconhecido enquanto influência mulçumana, chegou ao Brasil por volta do século XIX através dos escravos islamizados e também pelos portugueses da época. (MONTEIRO; FERREIRA, 2005, p.390).

Conforme Lara (2013), ao analisar alguns aspectos simbólicos dos trajes das mulheres negras, é possível afirmar que esses demarcam importante e específica linguagem visual. O uso dos adereços como panos, cachimbos, amuletos, tinham finalidades tanto ritualísticas como também profanas, mas eram potentes em expressão mesmo em meio a escravidão. De 
certa forma, através dos adornos que utilizavam era possível em diversas situações ostentar significativas heranças africanas.

Considerando o uso do turbante como símbolo de representatividade cultural, convém tratar sobre suas potencialidades enquanto patrimônio imaterial. Alusivo ao tema em questão, pode-se afirmar conforme dados do Instituto do Patrimônio Histórico e Artístico Nacional (2014) que, “os bens culturais de natureza imaterial dizem respeito àquelas práticas e domínios da vida social que se manifestam em saberes, ofícios e modos de fazer (...)”, dentre outros. Por ser algo hereditário, passa por constantes recriações.

Segundo Iphan (2014), a proteção dos patrimônios culturais se dá por meio de inventários, registros, tombamento, vigilância e desapropriação, dentre outras formas. Esses bens são caracterizados e adequados por indivíduos e grupos significativos a sua identidade. Por seu rico valor simbólico, os bens imateriais, cooperam com a difusão do respeito à diversidade cultural. Os bens culturais necessitam deter de continuidade histórica, bem como também ter possuem relevância para a memória do país, fazendo referência dos grupos sociais brasileiros.

Caracterizado como saberes integrantes da cultura das comunidades, o patrimônio imaterial gera sentimento de identidade e continuidade nos grupos populacionais. O Decreto $\mathrm{n}^{\circ} 3.551$ de 4 de agosto de 2000, deu início ao registro dos bens imateriais que constituem o patrimônio cultural brasileiro. As formas de registros visando destacar sua relevância para a memória, ocorrem mediante inscrições em livros sendo esses "Livro de Registro dos Saberes", Livro de Registro das Celebrações", "Livro de Registro das Formas de Expressão" e "Livro de Registro dos Lugares". Caso necessário pode-se abrir outros livros para inscrição dos bens culturais (IPHAN, 2000, p. 01).

A preocupação quanto aos bens culturais por parte do IPHAN deve considerar a propagação dos saberes de uma cultura. Prezando assim pela característica identitária de determinado grupo social em prol do reconhecimento da diversidade cultural dos fazeres e costumes existentes. Retomando o caso do turbante, convém salientar que o uso do mesmo aponta para um processo de formação cultural. Compreender suas origens culturais e discutir sobre a representatividade de seu uso passa pela valorização da identidade afro-brasileira. Segundo Poulot (1997), “a história do patrimônio é a história da construção do sentido de identidade e mais particularmente, dos imaginários de autenticidade que inspiram as políticas patrimoniais" (apud FERREIRA, 2006).

Por meio do turbante evidencia-se a ligação dos negros com seus costumes originais, simbolizando característica de resistência. A problemática em generalizar seu uso para 
brancos e negros, deve partir da compreensão de seu real significado, de suas histórias. Infelizmente muitas vezes os negros são vítimas de preconceito por entrarem em contato com suas raízes e adotarem este tipo de acessório em seu visual. Segundo a militante feminista Camila Lima, "enquanto um negro usava o turbante, tranças ou dreads, ele não era aceito em certos ambientes. Mas, a partir do momento que os brancos adotam estes itens, eles conseguem circular em todos os lugares e os elementos se tornam algo maneiro".

Para Ribeiro (2015), o uso do adorno não deve ser restrito, porém é necessário apontar que ainda hoje existe uma cultura dominante imposta e um modelo padrão europeu de estética. Ela comenta também que o uso pelos negros desses adereços causa olhares diferenciados. Quando é usado por esses protagonistas, perde-se o real significado político e de empoderamento.

\footnotetext{
Ao mesmo tempo em que se impõe o padrão de beleza branca-de-cabelos-lisos e se propaga a ideia de que o uso de turbante por negras é coisa de "macumbeira", o símbolo vira tendência da noite para o dia. Mas tendência para quem? As capas de revistas com mulheres usando turbantes mostram a mesma musa idealizada de sempre; visualmente, já se exclui a protagonista. Isso não é globalização, é um processo onde agora a moda é negra, mas o negro não está na moda, porque ser negro continua sendo ruim. Agora, ele não "pode" mais ser o agente principal da sua própria cultura. (Disponível em: < http://www.revistacapitolina.com.br/o-que-eapropriacao-cultural/> Acesso em 11.08.16).
}

Com base nos relatos acima, convém discutir sobre o que está sendo atrelado ao atual uso do turbante no Brasil. Suas relações de memória estabelecidas estão sendo expostas de forma equivocada. Em meio a um processo de comercialização de acessórios, percebe-se que as origens dos mesmos estão sendo inibidas. A lembrança afetiva atrelada ao uso do turbante deve-se ser sensibilizada em torno do simbolismo que o compõe. Um patrimônio passa por proteção de aspectos característicos do passado e valorização das representações de determinado objeto.

Considerando as duas perspectivas de memórias tem-se a memória social e psicológica. Segundo Costa (2008), a memória sociológica representa coletividade, enquanto que a psicológica pensa afetação do singular para o coletivo. É importante compreender a relação de trocas existente entre o indivíduo e o coletivo. Entendendo o uso do turbante enquanto patrimônio, pode-se se afirmar que se ancora em memórias entre os grupos sociais. Para haver preservação necessita-se que o simbolismo desse adorno se conserve nas lembranças dos indivíduos. Deve-se levar em conta também a diversidade cultural existente, difundindo saberes e bens tradicionais presentes nas memórias das comunidades. 

e-ISSN 2016/Atual: 2525-7870 | e-ISSN 2015/2016: 2447-018X

Alusivo à concepção de imaginário em torno da representatividade negra através do turbante, convém destacar que é decorrente de experiências vividas por diversos povos ancestrais e que se mantém na atualidade. Descendentes de cultura afro carregam elementos que simbolizam elo com o passado, como por exemplo os ritos religiosos e saberes ligados a suas tradições que compõem a paisagem cultural de suas ações. É de grande relevância considerar as afetividades e emoções em torno desse imaginário afim de contribuir com a preservação das memórias existentes.

\begin{abstract}
A paisagem envolve os elementos físicos/naturais, suas interações, assim como todas as intervenções e articulações provocadas pela ação humana. Desse modo, compõem a paisagem os elementos históricos e culturais que sinalizam o processo organizacional dos diversos grupos sociais, construídos ao longo do tempo. (Catrogiovanni Apud Costa 2005, p. 1).
\end{abstract}

Para Costa (2005), através da transmissão de conhecimentos e valores tem-se a representação da paisagem a qual atual como integrante de uma dinâmica cultural construída ao longo do tempo. Atribuindo esse conceito ao uso do turbante de origem afro é cabível considera-lo como símbolo de representatividade repassado de geração a geração, o qual no momento atual não recebe a devida legitimidade e reconhecimento social.

\title{
3. Sujeito-trama
}

Para Baptista (2004, p. 34), "Comunicação é interação de sujeitos, através do fluxo de informações entre eles, numa espécie de trama-teia complexa, composta tanto de elementos visíveis quanto invisíveis, corporais e incorporais, significantes e a-significantes". Cada sujeito decorre de subjetividades, as quais podem ser produzidas ou não por meios de comunicação. Recentemente no campo da representatividade negra, tem-se algumas contradições entre os sujeitos-tramas. Através da representação das vestimentas afros na moda e nas mídias sociais, tem-se gerado equívocos de comunicação entre os sujeitos.

$\mathrm{O}$ atual uso desmedido de dreads e turbantes que em negras muitas vezes é visto como algo de marginalidade, em pessoas brancas passam a ser aceitáveis. As marcações tribais existentes são atributos de contextos específicos e fazem parte de uma trama complexa de opiniões em torno de seus usos. O reconhecimento do uso do turbante enquanto adereço de representatividade negra, por exemplo, deve ser indispensável aos sujeitos em geral. Entender o simbolismo presente na história do turbante nesse contexto, evita que seu uso seja banalizado e sofra esvaziamento do real significado. 


\section{Considerações Finais}

O conceito de patrimônio cultural é amplo, se fazendo presente em inúmeras formas de manifestações culturais intangíveis. O desrespeito com a preservação de um patrimônio pode acarretar na perda de identidade e de seus valores. Refletir sobre a representatividade da identificação negra do turbante enquanto patrimônio, permite interpreta-lo em diversas possibilidades. Dentre elas, pode-se afirmar que sua característica enquanto imaterial é refletida no simbolismo que possui. Esse simbolismo se materializa no objeto que é utilizado. Sendo assim, não há como haver separação entre o material e imaterial sendo que estão simultaneamente interligados.

Enquanto paisagem cultural o uso do turbante reflete-se principalmente através das mulheres negras que mantém vivo o legado de seus ancestrais, difundindo o simbolismo presente no uso do acessório. Contradizendo os meios de comunicação massivos que atualmente mantém o protagonismo branco como representatividade cultural, existem blogueiras, ativistas e militantes de coletivos negros que atuam como mantenedoras dos ideais significativos de seus bens culturais, por meio de intervenções virtuais, oficinas práticas sobre o tema, dentre outras ações.

A preservação de memórias deve partir do princípio de pertencimento e afeto pelos bens. Patrimonializar o uso do turbante enquanto representatividade negra é uma forma de empoderamento político e social. Através da conscientização e sensibilização dos indivíduos quanto a importância do uso desse adorno, ativa-se o valor simbólico do mesmo. Assim, conforme os sujeitos se identificam culturalmente com suas tradições, agregam o devido reconhecimento cultural.

\section{Referências}

BAPTISTA, Maria. Comunicação, Amorosidade e Autopoiese. Universidade do Vale do Rio dos Sinos (UNISINOS), in: Congresso Brasileiro de Comunicação, 2004.

BORGES, Adriana. Turbante - Cultura, Moda e Estilo. Disponível em: http://obviousmag.org/my_cup_of_tea/2015/05/turbante-cultura-moda-e-estilo.html. Acesso em: 10 agosto 2016.

BRITO, Patrícia. Turbantes II: religião, moda e atitude. Disponível em: http://www.soulnegra.com/turbantes-ii-religiao-moda-e-atitude/. Acesso em:10/08/2016.

COSTA, Marli; CASTRO, Ricardo. Patrimônio Imaterial Nacional: preservando memórias ou construindo histórias?. Universidade do Estado do Rio de Janeiro, 2008. 

e-ISSN 2016/Atual: 2525-7870 | e-ISSN 2015/2016: 2447-018X

IPHAN. Patrimônio Imaterial. Disponível em: http://portal.iphan.gov.br/pagina/detalhes/234. Acesso em 07 agosto 2016.

LARA, Silvia. Mulheres Escravas, Identidades Africanas. Disponível em: http://www.desafio.ufba.br/gt3-006.html. Acesso em: 12 agosto 2016.

MONTEIRO, Juliana; FERREIRA, Luzia. As Roupas de Crioula no Século XIX e o Traje de Beca na Contemporaneidade: Símbolos de Identidade e Memória. Revista de Humanidades, Rio Grande do Norte, v. 07, n. 18, p. 382-403, 2005. ISSN -1518-3394. Disponível em www.cerescaico.ufrn.br/mneme. Acesso em: 10 agosto 2016.

RIBEIRO, Stephanie. O que é Apropriação Cultural?. Disponível em: http://www.revistacapitolina.com.br/o-que-e-apropriacao-cultural/. Acesso em: 13 agosto 2016. 